\title{
Economic Impact of NMMO Pretreatment on Ethanol and Biogas Production from Pinewood
}

\author{
Marzieh Shafiei, ${ }^{1}$ Keikhosro Karimi, ${ }^{1,2}$ Hamid Zilouei, ${ }^{1}$ and Mohammad J. Taherzadeh ${ }^{3}$ \\ ${ }^{1}$ Department of Chemical Engineering, Isfahan University of Technology, Isfahan 84156-83111, Iran \\ ${ }^{2}$ Industrial Biotechnology Group, Institute of Biotechnology and Bioengineering, Isfahan University of Technology, \\ Isfahan 84156-83111, Iran \\ ${ }^{3}$ Swedish Centre for Resource Recovery, University of Borås, 50190 Borås, Sweden \\ Correspondence should be addressed to Marzieh Shafiei; m.shafiei@ce.iut.ac.ir
}

Received 3 June 2014; Accepted 15 July 2014; Published 7 September 2014

Academic Editor: Meisam Tabatabaei

Copyright (c) 2014 Marzieh Shafiei et al. This is an open access article distributed under the Creative Commons Attribution License, which permits unrestricted use, distribution, and reproduction in any medium, provided the original work is properly cited.

Processes for ethanol and biogas (scenario 1) and biomethane (scenario 2) production from pinewood improved by Nmethylmorpholine-N-oxide (NMMO) pretreatment were developed and simulated by Aspen plus. These processes were compared with two processes using steam explosion instead of NMMO pretreatment ethanol (scenario 3) and biomethane (scenario 4) production, and the economies of all processes were evaluated by Aspen Process Economic Analyzer. Gasoline equivalent prices of the products including 25\% value added tax (VAT) and selling and distribution expenses for scenarios 1 to 4 were, respectively, $1.40,1.20,1.24$, and $1.04 € / 1$, which are lower than gasoline price. The profitability indexes for scenarios 1 to 4 were $1.14,0.93,1.16$, and 0.96 , respectively. Despite the lower manufacturing costs of biomethane, the profitability indexes of these processes were lower than those of the bioethanol processes, because of higher capital requirements. The results showed that taxing rule is an effective parameter on the economy of the biofuels. The gasoline equivalent prices of the biofuels were $15-37 \%$ lower than gasoline; however, $37 \%$ of the gasoline price contributes to energy and carbon dioxide tax which are not included in the prices of biofuels based on the Swedish taxation rules.

\section{Introduction}

Ethanol and biomethane are two common biofuels which are already available in the market in some countries. Ethanol is mainly produced from sugar and starch based raw materials. However, wide investigations are performed for replacement of these food based raw materials with cheaper and more abundant lignocellulosic materials [1]. Biogas is currently produced in wastewater treatment plants or from various organic wastes such as municipal solid waste, manure, and industrial and agricultural wastes [2]. Biogas from wastes is mainly used in the power plants, and the compressed biomethane is commercially available beside the compressed natural gas (CNG) as a vehicle fuel. Considering the predicted expansion of methane usage in Sweden, there would be an increasing market for biomethane to be used as a vehicle fuel. Moreover, further developments in natural gas grid support more injection of biomethane in the grid [3].
A pretreatment step prior to biofuel production from lignocellulosic materials is essential for improvement of the low yields [1,5-9]. Pretreatment with N-methyl morpholine$\mathrm{N}$-oxide (NMMO) is among the novel and efficient methods [5-7]. NMMO is a nontoxic cellulose solvent, does not produce toxic wastes, and can be recycled over $98 \%$ [6]. NMMO pretreatment modifies the structure of lignocellulosic materials to obtain higher yields of enzymatic hydrolysis and anaerobic digestion. During pretreatment, NMMO dissolves cellulose which is inside of the cell wall of wood. Afterwards, addition of water regenerates cellulose, and less crystalline and amorphous cellulose precipitates on the biomass surfaces. The hydrolysis of regenerated cellulose is much more convenient than the intact cellulose inside the cell wall. Furthermore, the pretreatment process increases the biomass porosity and consequently accessibility of degrading enzymes or bacteria to the inside of the biomass. Better accessibility to the inside of biomass results in enhanced 
yields of enzymatic hydrolysis and anaerobic digestion [5]. One of the important features of NMMO pretreatment is that physical removal of lignin and hemicellulose is not necessary to obtain a high cellulose hydrolysis yield. The modifications made by NMMO pretreatment are so efficient that the subsequent enzymatic hydrolysis yield is significantly higher than the yield after most of the other pretreatments, for example, steam explosion.

Another promising pretreatment process is steam explosion. Although it has a lower efficiency compared with NMMO pretreatment, it is a simple method that is well investigated in laboratory and pilot scales and is suggested for industrial scale applications [1].

Biofuel production from lignocellulosic materials is a developing technology and still challenging with technical and economical bottlenecks. Technoeconomic analysis helps to overcome these problems using process simulation tools together with economic analysis [10]. Several technoeconomic analyses were performed for bioethanol production from lignocelluloses [10-12]. The economics of biogas production from lignocellulosic materials were also studied $[2,3$, 13]. However, no reference was detected for technoeconomic comparison of NMMO and steam explosion pretreatment for both bioethanol and biogas production from lignocellulosic materials.

Significant improvements in the ethanol and biogas yields from NMMO treated pinewood were observed [5]. In the current study, based on the experimental results, the economics of the processes for bioethanol and biogas productions with NMMO pretreatment were compared with two processes using continuous steam explosion pretreatment for similar products. The processes were simulated and optimized using Aspen plus, and the economics were evaluated with Aspen Process Economic Analyzer (PEA). A sensitivity analysis was also performed to determine the effective parameters.

\section{Methods}

Four scenarios for production of bioethanol and biogas using steam explosion or NMMO pretreatment were developed. The process for each scenario was simulated by Aspen plus, and then the economy was studied by Aspen PEA. The selected raw material was pinewood because of availability of the experimental results [5]; however, other lignocellulosic feedstocks can be used with some minor modifications.

2.1. Process Development. This study includes four main scenarios. In the first two scenarios, NMMO pretreatment is used for improvement of ethanol and biogas production (scenario 1) and for only biogas production (scenario 2 ). The other two scenarios are for the production of the similar products but steam explosion pretreatment is used instead of NMMO pretreatment (scenarios 3 and 4).

2.1.1. Scenario 1: NMMO Pretreatment for Improvement of Ethanol and Biogas Production. The raw materials are unloaded from trucks to storage area and conveyed for size reduction. All of the scenarios include similar units for the feedstock handling area. In scenario 1 (Figure 1), raw materials are reduced in size and then pretreated with NMMO for 3 hours at $120^{\circ} \mathrm{C}$ (Figure 2). Then, the materials are regenerated by addition of hot water, washed with water to remove NMMO, and then sent to the biofuel production process. An optimized evaporation unit is used for the recovery and concentration of NMMO (Table 1) [12].

In scenario 1 , the wood is washed with water after the pretreatment and the water containing $70 \% \mathrm{NMMO}$ is sent to evaporation. The evaporation concentrates NMMO to $85 \%$, and it is reused in the pretreatment. A makeup stream for NMMO is considered in the process to supply the amount of NMMO which is not recovered during the washing of the treated wood. Based on the calculations, the NMMO recovery of $99.5 \%$ is required to have an economically feasible process. Efficient multistage countercurrent equipment for solid washing is considered to provide this recovery. During the pretreatment, addition of antioxidant agents prevented the oxidation and degradation of NMMO.

Ethanol production includes hydrolysis, nonisothermal simultaneous saccharification and fermentation (NSSF), distillation, and dehydration. After pretreatment, the raw materials are hydrolyzed with Cellic CTec3 enzyme (Novozymes) for 24 hours. It is claimed that this newly developed enzyme has a higher efficiency compared with the previous types of the Cellic enzymes $[12,14]$. Because of improvements in the enzyme efficiency, the enzyme is loaded at the rate of $1.8 \%$ $\mathrm{w} / \mathrm{w}$ of cellulose [12]. The hydrolysis temperature is set to $45^{\circ} \mathrm{C}$ for better stability. Afterwards, the hydrolysate is cooled down to $37^{\circ} \mathrm{C}$ for SSF fermentation for 24 hours [12]. Four main fermenters and four hydrolysis reactors are designed with volumes of $800 \mathrm{~m}^{3}$. For each of the hydrolysis and fermentation reactors, seed fermenters with relative volume ratio of 1:10 until volume of 801 are used for inoculum preparation. All fermenters and auxiliary equipment are made up of stainless steel 304.

The distillation, dehydration, and wastewater treatment (WWT) units are similar to the systems presented by Shafiei et al. [12] with modifications for the new raw material and lower capacity. The distillation unit system (Figure 3 and Table 2) purifies ethanol to $95.5 \%$. For further purification to $99.9 \%$, a molecular sieve unit is used. The ethanol recovery was assumed to be $96 \%$ in the distillation unit. Afterwards, the wastewater from the striper column is filtered for solid removal and then sent to an anaerobic digester of UASB type for biogas production. This system removes $90 \%$ of the COD, and the effluent is further purified using aerobic digestion [12]. The biogas produced in this process is not sufficient to have an economically feasible upgrading; therefore, it is sold to a nearby combined heat and power (CHP) plant. An amount of $6 \%$ biogas loss was assumed during the storage [15].

2.1.2. Scenario 2: NMMO Pretreatment for Improvement of Biogas Production. The block flow diagram (BFD) for scenario 2 is presented in Figure 4. Similar to scenario 1, units for feed handling and NMMO pretreatment were assumed for this scenario. The treated materials are then conveyed to the 


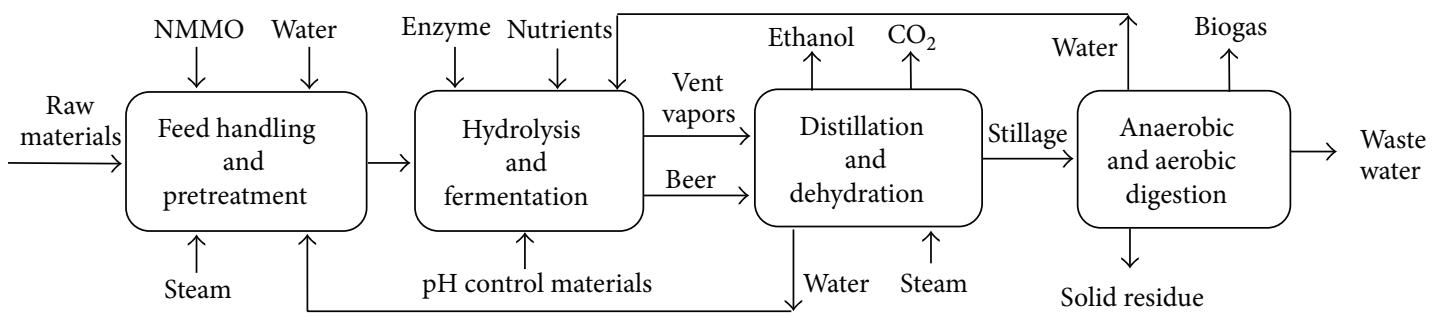

FIGURE 1: Block flow diagram (BFD) of scenario 1: NMMO pretreatment for production of ethanol and biogas.

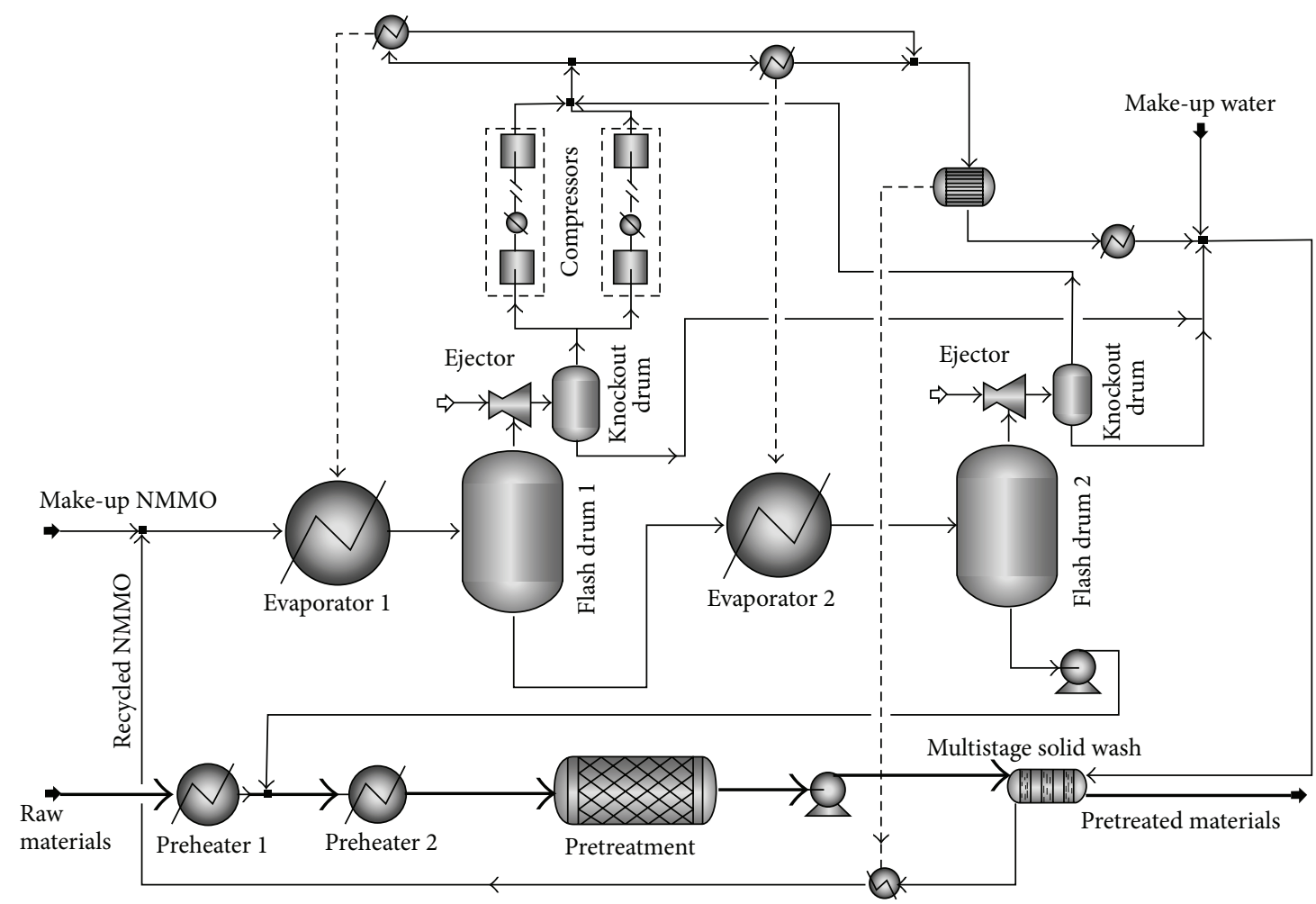

FIGURE 2: PFD of NMMO pretreatment unit. The optimized mechanical vapor recompression (MVR) system was used for the evaporators (scenarios 1 and 2).

solid-state biogas production unit presented by DRANCO (Germany) [16] (Figure 5). Seven digesters with volume of $3200 \mathrm{~m}^{3}$ made of acid resistant coated carbon steel are used in the process. The digesters are vertical cone bottom vessels and are fed using screw pumps. A portion of the outflow is mixed with the pretreated wood and nutrients are sent back to the top of digesters so the overall retention time of materials is 20 days $[13,16]$. The digested materials are dewatered to $30 \%$ solid content and sold as a byproduct for combustion. Macrofilters and reverse osmosis system are used for water purification, while $80 \%$ of the water is recycled to the process [17]. The effluent water is treated using aerobic digestion [12]. The produced biogas is upgraded to $97 \%$ with water scrubbing technology with regeneration and then pressurized for further application as fuel. Methane losses are estimated to be $1.5 \%$ in the upgrading process and $6 \%$ during the storage [15].
2.1.3. Scenario 3: Steam Explosion Pretreatment for Improvement of Ethanol and Biogas Production. The BFD for scenario 3 is presented in Figure 6. The feedstock is handled in an area similar to the previous scenarios. Afterwards, the feedstock is conveyed to the pretreatment area where it is subjected to continuous steam explosion pretreatment (Figure 7). The process design was similar to the process presented by Shafiei et al. [13] with some modifications for the new raw material and lower capacity. Briefly, the system consists of three parallel pretreatment units, each of them has screw conveyors, presteamer, flash vessel, pretreatment reactor, and expansion tank. The treated materials are used for bioethanol production in a process similar to scenario 1. Moreover, the dehydration and wastewater treatment units are similar to scenario 1 [12]. The raw biogas is sold as a byproduct for heat and power generation. 


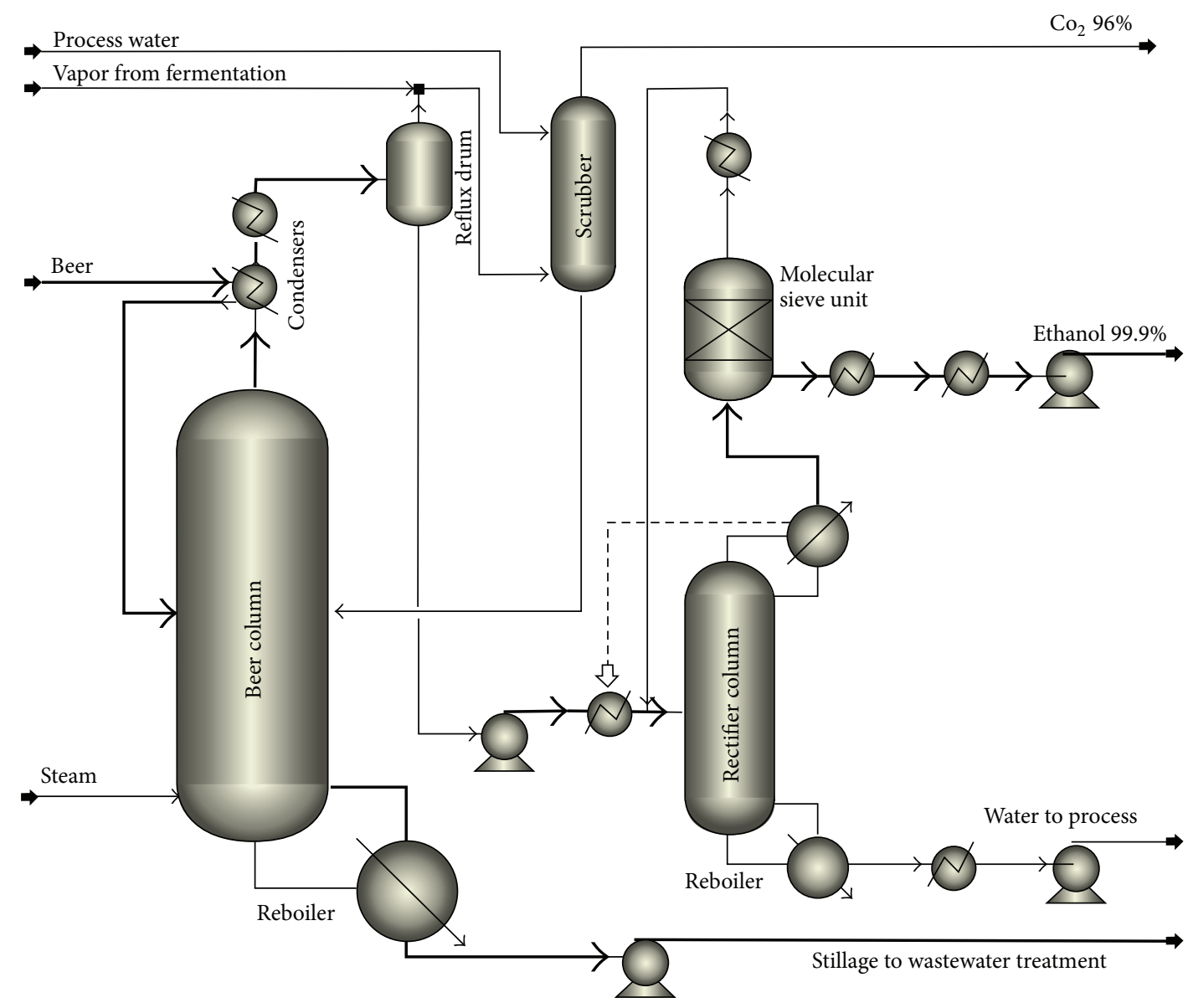

FIGURE 3: PFD of distillation unit. Beer is processed by a beer column, a rectifier column, and a molecular sieve unit and the product is fuel ethanol (scenarios 1 and 3).

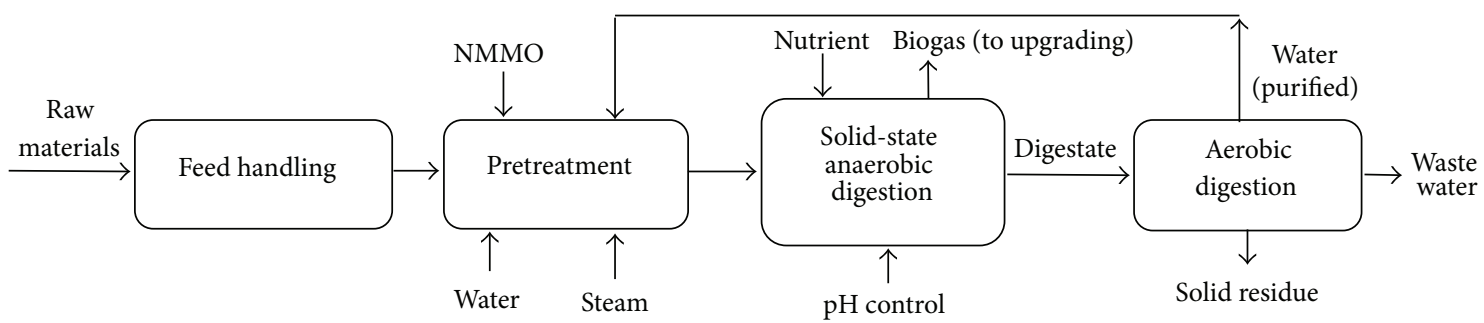

FIGURE 4: BFD of scenario 2: NMMO pretreatment for production of biomethane.

TABLE 1: The process conditions for the equipment of NMMO pretreatment in Figure 2.

\begin{tabular}{lccccccccc}
\hline $\begin{array}{l}\text { Equipment/ } \\
\text { conditions }\end{array}$ & Preheater 1 & Preheater 2 & Pretreatment & $\begin{array}{c}\text { Multistage } \\
\text { solid wash }\end{array}$ & Evaporator 1 & $\begin{array}{c}\text { Flash } \\
\text { drum 1 }\end{array}$ & Evaporator 2 & $\begin{array}{c}\text { Flash } \\
\text { drum 2 }\end{array}$ & $\begin{array}{c}\text { Compressor } \\
\text { Input } T\left({ }^{\circ} \mathrm{C}\right)\end{array}$ \\
\hline 20 & 90 & 120 & $120^{\mathrm{a}}, 45^{\mathrm{b}}$ & 87.3 & 79.8 & 79.8 & 90 & 100 \\
Output $T\left({ }^{\circ} \mathrm{C}\right)$ & 90 & 120 & 120 & $45^{\mathrm{a}}, 62^{\mathrm{b}}$ & 79.8 & 79.8 & 90 & 90 & 170 \\
Input $P$ (barg) & 0 & 0 & 0.5 & 3 & 0 & -0.78 & -0.78 & -0.97 & 0 \\
Output $P$ (barg) & 0 & 0.5 & 0.5 & 3 & -0.78 & -0.78 & -0.97 & -0.97 & 0.64 \\
\hline
\end{tabular}

${ }^{\mathrm{a}}$ The temperature of main streams.

${ }^{\mathrm{b}}$ Temperature of washing water. 


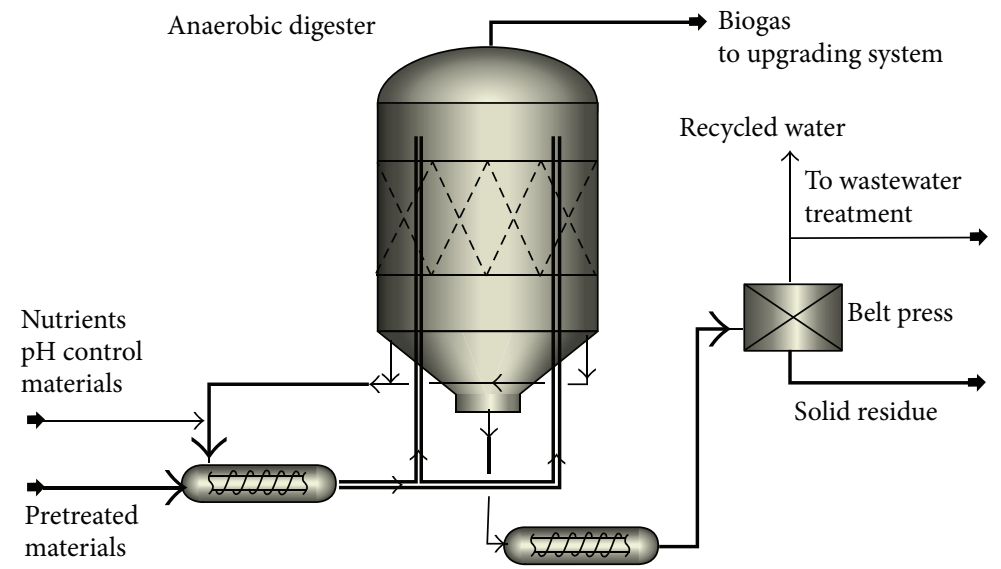

FIGURE 5: PFD of solid-state biogas production unit (scenarios 2 and 4).

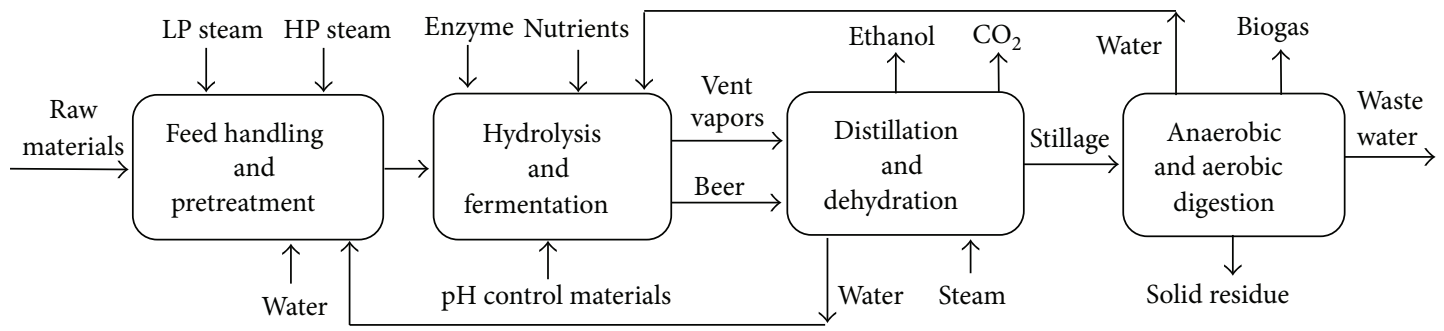

FIGURE 6: BFD of scenario 3: steam explosion pretreatment for production of ethanol and biogas.

2.1.4. Scenario 4: Steam Explosion Pretreatment for Improvement of Biogas Production. In scenario 4 (Figure 8), the feedstock handling and pretreatment area are similar to scenario 3. However, the materials are sent for solid-state biogas production in a process similar to scenario 2 . The water from the process is purified using macrofilters and reverse osmosis system and partially recycled to the process. Complete recycling is not possible due to accumulation of some ions and chemicals in the process. The biogas is upgraded and pressurized in a process similar to scenario 2 $[17,18]$.

2.2. Plant Location and Capacity. Sweden was selected for the plant location because of its large biofuel vehicle fleet in Europe [19]. In order to support the economy of the biofuel production plant, it is necessary to locate it nearby a CHP plant. In such a way, a part of capital costs for steam and electricity production is reduced. Several CHP plants are already built in Sweden for production of energy from wood, municipal waste, and forest biomass. Most of the CHP plants in the main cities of Sweden are large enough to support the electricity and steam requirement of the biofuel plant. For instance, each of the CHP plants in Stockholm area produces 800-1700 GW heat and 200-750 GW electricity [20]. Finally, the availability of raw material and transportation costs would affect the final decision for exact selection of the plant location.

Wood is already used in Sweden for energy production. For example, in Brista plant in Stockholm, 350,000 ton per year of wood chips is used [20]. In this study, the plants were designed for utilization of 100,000 ton/year pinewood which have a half of the capacity of previous studies [12]. The wooden raw material required for this plant is around $1 \%$ of the total amount of 16 million $\mathrm{m}^{3}$ of sawn wood (spruce and pine) produced in Sweden [21].

Biogas, the byproduct of scenarios 1 and 3, can be sold to the CHP plant for combustion. Solid residue, another byproduct of the processes, contains about $30 \%$ dry material. Over $70 \%$ of the dry material of solid residue is lignin, and other main materials are cellulose, hemicellulose, and biomass. Solid residue may be further used in gasification, pyrolysis, or combustion processes. However, presence of water in the solid residue is one of the major challenges for gasification and pyrolysis [22]. Thus, solid residue is sold to the CHP plant for burning.

2.3. Process Simulation and Economic Evaluation. The main equipment of the four processes was simulated by Aspen 


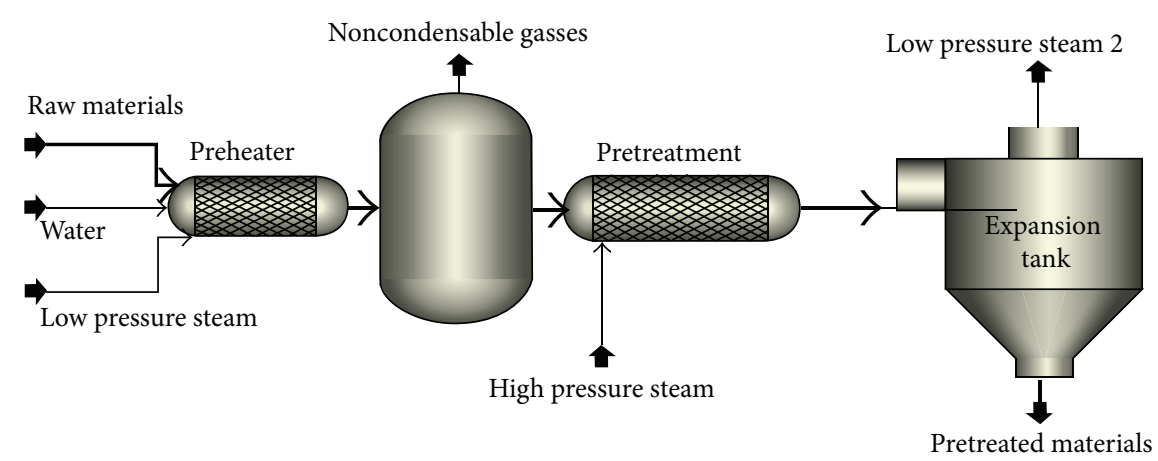

FIGURE 7: PFD of steam explosion pretreatment unit (scenarios 3 and 4).

TABLE 2: The process conditions for equipment of ethanol distillation in Figure 3.

\begin{tabular}{lcccc}
\hline Equipment/conditions & Beer column & Scrubber column & Rectifier column & Molecular sieve unit \\
\hline Top input $T\left({ }^{\circ} \mathrm{C}\right)$ & $50^{\mathrm{a}}, 40^{\mathrm{b}}$ & 25 & - & 90 \\
Bottom input $T\left({ }^{\circ} \mathrm{C}\right)$ & 110 & 39 & 106 & 106 \\
Top output $T\left({ }^{\circ} \mathrm{C}\right)$ & 60 & 39 & 132 & 103 \\
Bottom output $T\left({ }^{\circ} \mathrm{C}\right)$ & 67.6 & 40 & - & 103 \\
Top input $P$ (barg) & $0.5^{\mathrm{a}}, 0.5^{\mathrm{b}}$ & 1 & 3 & - \\
Bottom input $P$ (barg) & 0.43 & 0 & 1.9 & 1.9 \\
Top output $P$ (barg) & -0.81 & -0.1 & 2.2 & 0.8 \\
Bottom output $P$ (barg) & -0.61 & 0 & 35 & 0.8 \\
Number of trays & 30 & 10 & & Packed \\
\hline
\end{tabular}

${ }^{a}$ The temperature of feed stream.

${ }^{b}$ The temperature of stream from scrubber.

plus simulation software. Unique features of this software are handling of materials in solid state and broad property data bank, which are beneficial for the best design, simulation, and optimization of the processes [23]. The software does the rigorous calculations for the equipment using a detailed model and determines the mass and energy in all streams of the process. For the physical and thermodynamic properties of the wood, a data bank prepared by NREL (National Renewable Energy Laboratory, USA) [24] was introduced to the software.

Based on the results from simulation, equipment sizing and optimization were performed using Aspen plus and Aspen PEA. Afterwards, the costs were estimated for all major equipment with Aspen PEA. The cost for some units was estimated based on the literature: ethanol dehydration unit [25], steam explosion equipment [25], and biogas upgrading and pressurizing [26]. Basic assumptions for economic evaluation are similar to the previous studies [13] with the following modifications.

(i) The capacity is reduced to 100,000 ton of dry materials per year.

(ii) Chemical engineering cost index of 2014 was used for the cost estimations.

(iii) The construction periods for scenarios 1 to 4 are 20, 36, 21, and 30 weeks per Aspen PEA suggestion.
The manufacturing costs of ethanol and biomethane were calculated according to the method presented by Peters and Timmerhaus [27]; however, the credit of the byproducts was subtracted from the manufacturing cost.

2.4. Sensitivity Analysis. A sensitivity analysis was performed to determine the most effective parameters (among the raw materials and byproducts) in the economy of the process. For the better comparison of four scenarios, the gasoline equivalent prices of the products were calculated using the lower heating values of the fuels which are $36.1 \mathrm{MJ} / \mathrm{Nm}^{3}$ for biomethane, 21.2 MJ/l for bioethanol, and 32.0 MJ/l for gasoline.

\section{Results and Discussion}

Based on the experimental results [5], two scenarios for production of bioethanol and biogas using NMMO pretreatment were developed. The economy of these two scenarios was compared with the economy of two similar scenarios with steam explosion pretreatment.

3.1. Mass and Energy Balances. Four scenarios for the production of bioethanol and biogas were simulated by Aspen plus (Figures 2, 3, 5, and 7). Based on the simulation results, the required raw materials and utilities as well as product specifications are shown in Table 3. Because of the better 
TABLE 3: The amount of raw materials/products and utilities used/produced in each scenario.

\begin{tabular}{|c|c|c|c|c|c|}
\hline & Scenario 1 & Scenario 2 & Scenario 3 & Scenario 4 & Price $(€ / \mathrm{kg})$ \\
\hline \multicolumn{6}{|l|}{ Raw materials (tpy) ${ }^{1}$} \\
\hline Pinewood (wet) & 105,263 & 105,263 & 105,263 & 105,263 & 0.06 \\
\hline Nutrients & 1100 & 200 & 1100 & 200 & 0.6 \\
\hline $\mathrm{pH}$ control & 200 & 1220 & 200 & 1220 & $0.24 / 0.15^{2}$ \\
\hline Enzymes & 1,512 & & 1,512 & & 1.226 \\
\hline NMMO & 1,536 & 1,536 & & & 4 \\
\hline \multicolumn{6}{|l|}{ Products (tpy) ${ }^{3}$} \\
\hline Methane $\left(\mathrm{m}^{3} / \mathrm{y}\right)$ & & $21,387,468$ & & $16,538,970$ & $1.15^{4}$ \\
\hline $\operatorname{Biogas}\left(\mathrm{m}^{3} / \mathrm{y}\right)$ & $5,952,956$ & & $5,217,778$ & & $0.75^{5}$ \\
\hline Solid residue (lignin) & 51,317 & 51,248 & 56,884 & 59,112 & 0.04 \\
\hline LP steam $2^{6}$ & & & 61,912 & 61,920 & 0.003 \\
\hline Ethanol $\left(\mathrm{m}^{3} / \mathrm{y}\right)$ & 30,015 & & 22,132 & & $0.85^{7}$ \\
\hline $\mathrm{CO}_{2}$ & 21,921 & & 18,480 & & 0.05 \\
\hline Sludge from WWT & 250 & 3,879 & 232 & 3,612 & 0.04 \\
\hline \multicolumn{6}{|l|}{ Utilities (tpy) } \\
\hline Process water & 166,324 & 123,815 & 121,424 & 62,264 & 0.0001 \\
\hline LP steam ${ }^{6}$ & & & 30,500 & 30,500 & 0.004 \\
\hline HP steam ${ }^{8}$ & 32,324 & 3,154 & 89,171 & 60,000 & 0.008 \\
\hline Electricity (Mwh) & 17,964 & 18,076 & 14,086 & 14,379 & 30 \\
\hline
\end{tabular}

${ }^{1}$ tpy: ton per year

${ }^{2}$ The main material for controlling $\mathrm{pH}$ in fermentation is $\mathrm{NaOH}$ solution $(0.24 € / \mathrm{kg})$. In anaerobic digestion sodium carbonate $(0.15 € / \mathrm{kg})$ is mainly added for maintaining the buffering capacity.

${ }^{3}$ tpy: ton per year, unless stated.

${ }^{4}$ The biomethane is sold at price of $1.15 € / \mathrm{m}^{3}$, which excludes VAT and selling and distribution costs.

${ }^{5}$ The biogas is sold at price of $0.75 € / \mathrm{m}^{3}$, which excludes VAT and selling and distribution costs.

${ }^{6} \mathrm{LP}$ steam: low pressure steam.

${ }^{7}$ The price unit is $0.85 € /$ lit of bioethanol (99.9\%). The price excludes VAT and selling and distribution costs.

${ }^{8} \mathrm{HP}$ steam: high pressure steam.

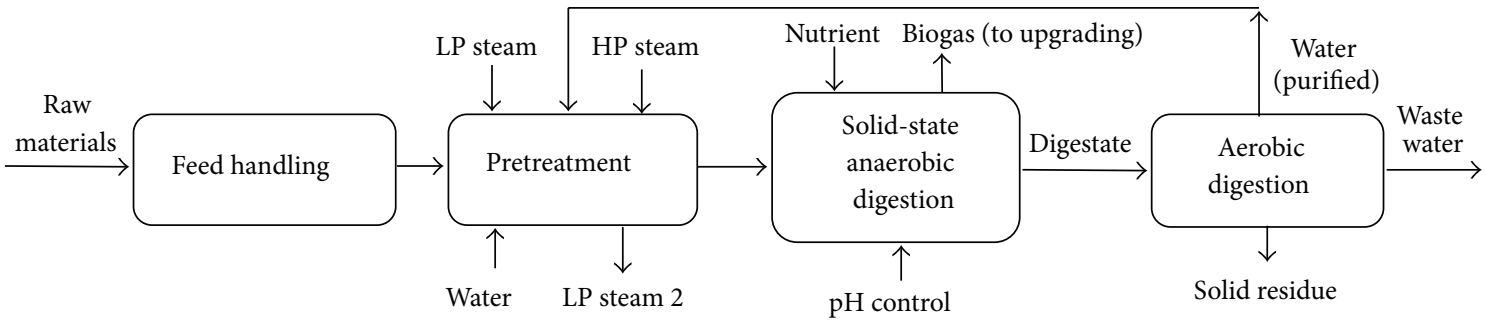

FIGURE 8: BFD of scenario 4: steam explosion pretreatment for production of biomethane.

efficiency of the NMMO pretreatment, the amount of ethanol and biogas in scenarios 1 and 2 was higher compared to scenarios 3 and 4 . Therefore, better hydrolysis and digestion in scenarios 1 and 2 lead to production of less solid residues. After steam explosion, the exhaust steam from the expansion tanks can be returned to the CHP plant to be reused in the process. This steam contains $0.15 \%$ volatile furans which must be removed before being reused. Carbon dioxide is produced in all of the processes. The purity of carbon dioxide from bioethanol process is over 99\%, and it can be sold as a byproduct; however, in the biomethane scenarios, it contributes to about $50 \%$ of the raw biogas and cannot be sold.
3.2. Total Project Investment. Total project investments calculated by Aspen PEA for scenarios 1 to 4 were 44.0, 69.7, 40.5, and 65.1 million $€$, respectively. The required capital for NMMO pretreatment was significantly higher than that for the steam explosion pretreatment (Table 4). Although ethanol production required more operating units, that is, hydrolysis, distillation, and dehydration, the facilities for biogas production were more expensive than the equipment required for ethanol production. The digesters were more expensive since the anaerobic digestion requires longer retention time of the materials (20 days) compared with 48 hours for the hydrolysis and fermentation in the ethanol production (Table 4). Additionally, the capital for the biogas upgrading 


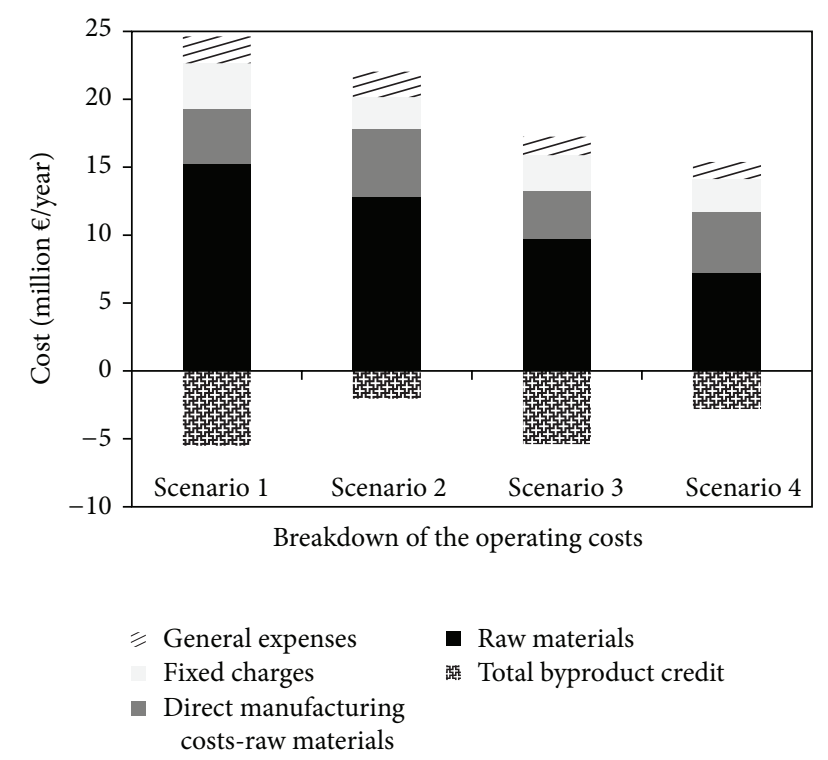

FIGURE 9: Breakdown of the operating costs for different scenarios.

and pressurizing was more expensive compared with the equipment for distillation and dehydration of ethanol.

3.3. Cost Distributions. The breakdown of the operating costs is depicted in Figure 9. The direct manufacturing costs include the costs for raw materials; operating labor and direct supervisory; utilities, maintenance, and repairs; and operating charges. The fixed charges include 30\% taxation on the plant income as well as the plant overhead. General expenses include the costs for research and development and financing (10\% return rate) and administrative costs. NMMO, lignocellulosic feedstock, and the enzymes are the most costly raw materials. The byproducts of bioethanol plants are biogas, solid residue, and carbon dioxide, while solid residue is the only byproduct of the biogas plants.

3.4. Manufacturing Costs and Gasoline Equivalent Prices. In Sweden, taxes are applied on the plant income as well as $25 \%$ value added tax on the final price of the products. Additionally, two other taxes are applied on the fossil fuels, but not on the biofuels, which are taxes for energy and carbon dioxide. The amounts of these taxes for gasoline were correspondingly 2.97 and 2.38 SEK/l in 2013. Therefore, tax contributes to $58 \%$ of gasoline price [4]. The portion of each of the taxes on the final prices of the biofuels is presented in Table 5. The average price of E85 (fuel ethanol) [28] was $1.14 € / 1(9.85 \mathrm{SEK} / \mathrm{l}$ converted based on the average Euro price in 2013 [29]). The manufacturing costs were calculated with considering all the parameters presented in Figure 9, including 30\% tax on the plant income. The manufacturing costs of ethanol for scenarios 1 and 3, excluding VAT and selling and distribution costs, were calculated to be 0.64 or $0.54 € / 1$, respectively. The final price for bioethanol including the costs for selling and distribution and the taxes for scenarios 1 and 3 would be $0.93 € / 1$ and $0.83 € / 1$, respectively. These prices are still lower than the fuel ethanol as well as gasoline (Table 5). The manufacturing costs of the biomethane $(97 \%$, pressurized, including plant income tax, VAT, and selling and distribution costs) for scenarios 2 and 4 were calculated to be 1.35 and $1.17 € / \mathrm{Nm}^{3}$ methane, respectively.

The gasoline equivalent prices of the final products, ready for selling at station, are presented in Table 5. The gasoline equivalent prices of all scenarios are lower than the average of gasoline price; however, the safe margin for scenario 1 is lower than other processes. Scenario 4 presents the best product price while scenario 1 shows the highest product price. Despite the better efficiency of the NMMO pretreatment, higher capital and higher raw material expenses of this process have led to higher manufacturing costs for ethanol (scenario 1 compared with scenario 3 ) and biogas (scenario 2 compared with scenario 4 ). Another point is that the processes for production of biogas were not as profitable as the ethanol processes, since investment costs for biomethane production are significantly higher than those of the bioethanol process.

The gasoline equivalent expenses of E85 and biomethane 100 are $4 \%$ and $16 \%$ lower than gasoline, and the prices for the four scenarios are 15-37\% less than the fossil fuel. However, only addition of energy and carbon dioxide taxes to the fossil fuels helped the competition of biofuels in the fuel market. Furthermore, there are other bonuses for biofuel vehicles, such as discount on car insurance, free parking spaces, lower annual registration taxes, and exemption from Stockholm congestion tax. Note that the manufacturing cost must be lower than the selling price to earn enough profit.

3.5. Sensitivity Analysis. The effects of price of the most important raw materials on the production cost of ethanol and methane are presented in Figure 10. While other raw materials, for example, nutrients and utilities, did not significantly affect the operating expenses (data not shown), the results of sensitivity analysis indicate that NMMO price had the most significant effect on the manufacturing cost of the products (Figures 10(b), 10(e), and 10(g)) (scenarios 1 and 2). For example, $50 \%$ increase in the price of NMMO results in $11 \%$ increase in the gasoline equivalent prices. The next two effective parameters are the price of the lignocellulosic feedstock (Figures 10(a), 10(d), and 10(f)) and the enzyme price (Figures $10(\mathrm{c})$ and $10(\mathrm{~h})$ ). Increasing $50 \%$ in the wood price has led to $8 \%, 8 \%, 13 \%$, and $12 \%$ of the gasoline equivalent prices of scenarios 1 to 4 , respectively. About $50 \%$ increase in the enzyme price for scenarios 1 and 3 has led to $3 \%$ and $4 \%$ increase in the gasoline equivalent prices, correspondingly. The processes for production of bioethanol had the least safe margin if they are compared with the average petrol price $(1.65 € / 1)$ in Sweden market (Figure 10).

The effects of byproduct prices on the manufacturing cost of the main products are presented in Figure 11. The data present the comparison of earning no profit from the byproduct or $50 \%$ increase in the byproduct price with the base cases. For scenarios 1 and 3, the credit from biogas and solid residue significantly affected the manufacturing costs (Figures $11(\mathrm{a})$ and $11(\mathrm{c})$ ). For both scenarios 1 and $3, \mathrm{CO}_{2}$ 


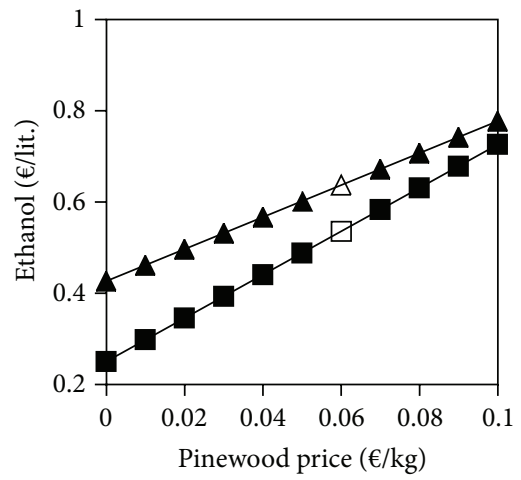

(a)

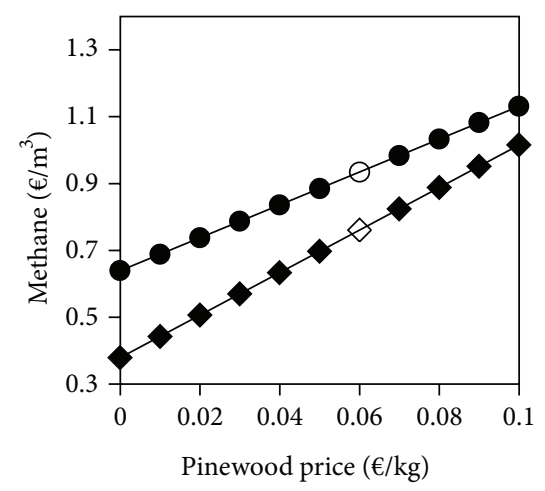

(d)

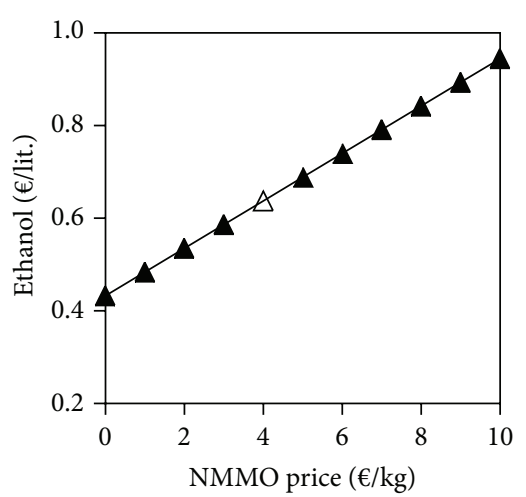

(b)

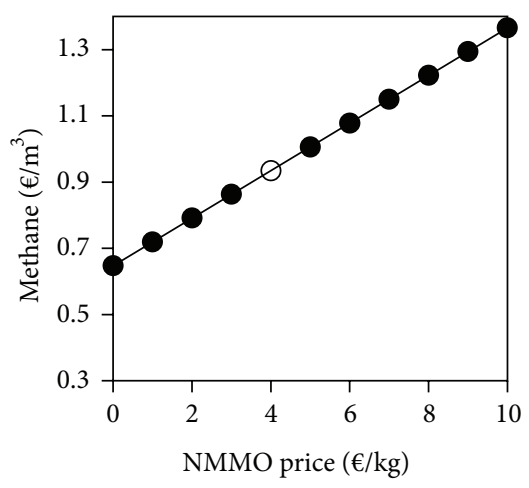

(e)

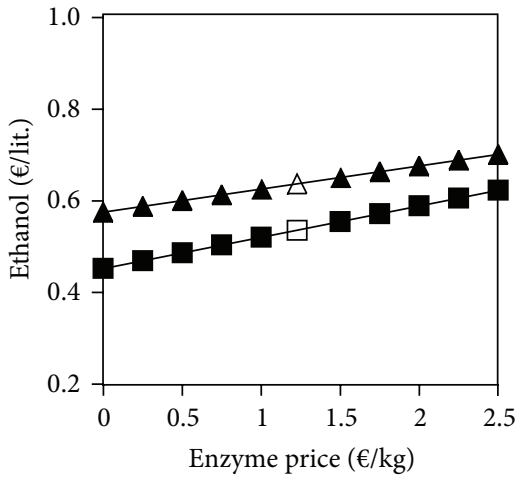

(c)

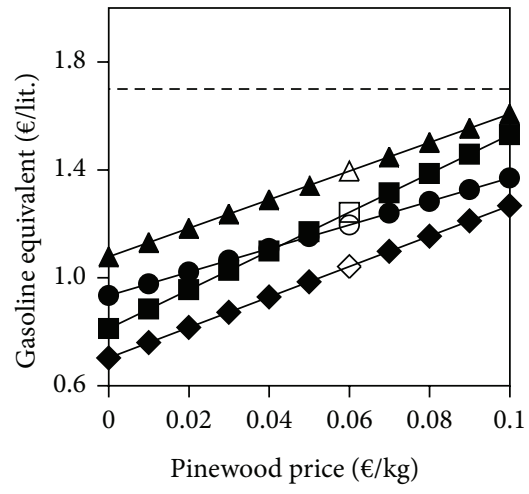

(f)

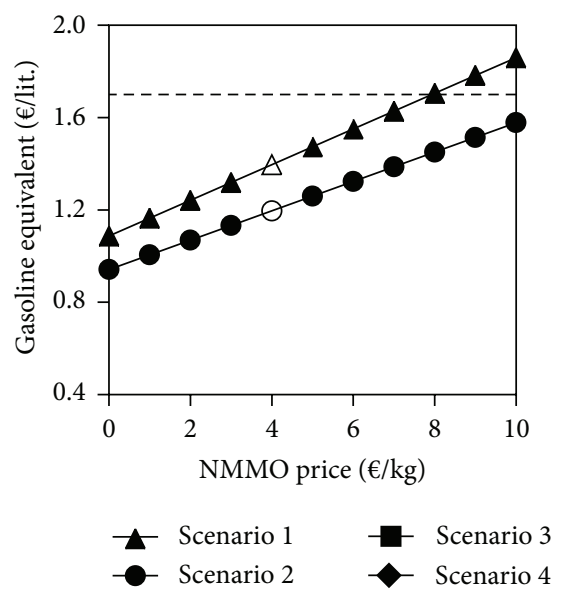

(g)

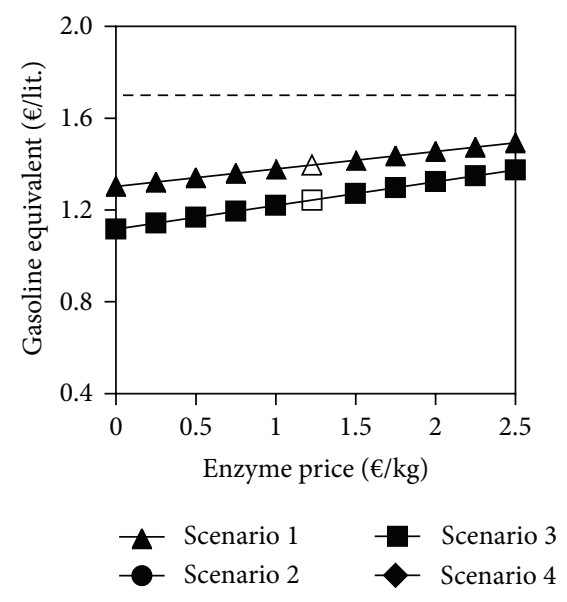

(h)

FiguRE 10: Effects of the price of wood, NMMO, and enzymes on the manufacturing cost of ethanol ((a), (b), and (c)), methane ((d), (e)), and the gasoline equivalent prices $((\mathrm{f}),(\mathrm{g})$, and $(\mathrm{h}))$ for scenarios $1(\boldsymbol{\Delta}), 2(\boldsymbol{\bullet}), 3(\boldsymbol{\bullet})$, and $4(\bullet)$. The dashed line corresponds to average gasoline price in the market. The empty shapes represent the base case values of manufacturing costs. The plant income tax is included in the calculation of the values, but VAT and selling and distribution costs were not added. The gasoline equivalent prices are the prices of ready products and include all expenses (c.f. Table 5).

had the least influence on the ethanol price. The price of solid residue was more effective in the manufacturing cost of methane in scenario 4 compared with scenario 2 (Figures 11(b) and 11(d)). The reason was lower efficiency of steam explosion pretreatment compared to NMMO pretreatment which results in lower digestion yield (scenario 4) and production of more solid residues (Table 3).
3.6. Profitability of the Processes. Discounted cash flow analysis for each scenario was performed using total capital investment and the annual operating costs. The costs include interests and time value of money. The payback period (payout period) for each scenario was calculated (Table 6 ) as the minimum length of time to recover the original capital investment. The payback period of the biogas plants was more than that 


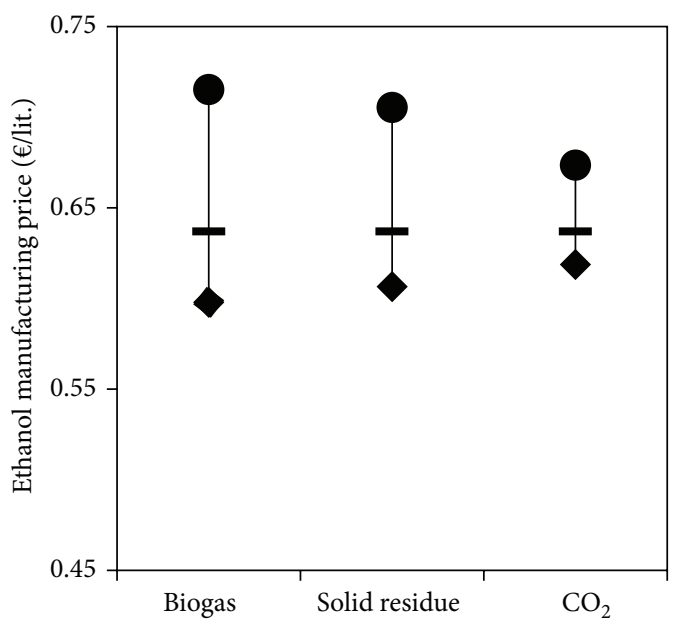

(a)

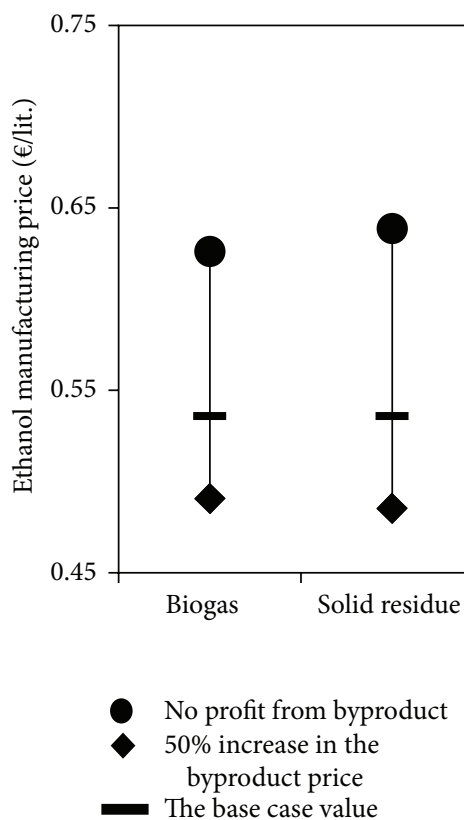

(c)

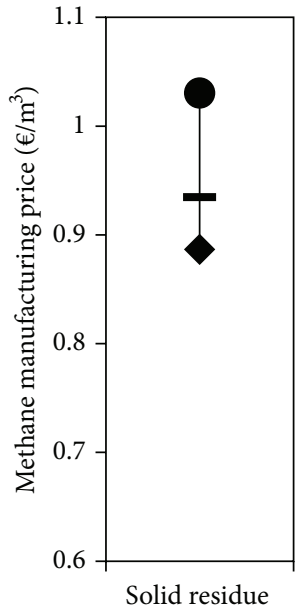

(b)

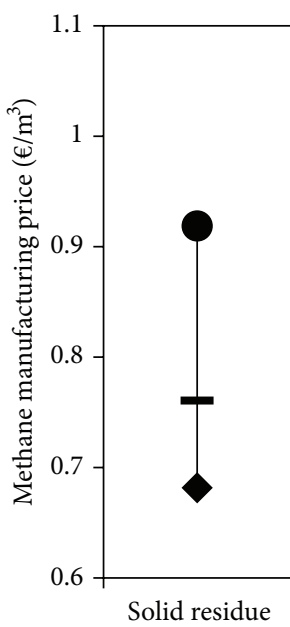

No profit from byproduct

$50 \%$ increase in the byproduct price

The base case value

(d)

FIGURE 11: Effect of byproduct price on the manufacturing cost of ethanol and methane for scenarios 1 (a), 2 (b), 3 (c), and 4 (d). The values are prices before addition of VAT and selling and distribution costs.

of the bioethanol plant because of the higher capitals requirements. Net rate of return (NRR) shows the profitability of the processes and was calculated by dividing the net present value (NPV) by the present value (PV) of cumulative outflows. The NRR for ethanol production processes was positive while processes for biomethane production had negative NRR (Table 6).

The relative profitability of the processes is presented by profitability index (PI) (Table 6). PI shows the present value of benefits relative to the present value of costs; thus, the PI of a profitable project must be greater than one. The processes for ethanol production (scenarios 1 and 3 ) were profitable (PI $>1$ ) and the processes for production of biomethane were not profitable $(\mathrm{PI}<1)$.

\section{Conclusions}

Both NMMO and steam explosion led to economically feasible processes for ethanol production (PI $>1$ ); however, none of the biomethane production processes were profitable (PI $<$ 1). Therefore, production of biomethane as the only product from wood may not be economically profitable. However, biogas production from the waste streams of ethanol process considerably helps the economy of the process and reduces the negative environmental impacts. The processes using steam explosion pretreatment were more economically profitable compared to the processes with NMMO pretreatment. Although the pretreatment type significantly affects the yield of final product and consequently the economy of the 
TABLE 4: Total project investment and its breakdown for the scenarios.

\begin{tabular}{|c|c|c|c|c|}
\hline Scenario & 1 & 2 & 3 & 4 \\
\hline Pretreatment & NMMO & NMMO & Steam explosion & Steam explosion \\
\hline Product & Ethanol/biogas & Biomethane & Ethanol/biogas & Biomethane \\
\hline \multicolumn{5}{|l|}{ Investment cost (million $€$ ) } \\
\hline Feed handling & 5.6 & 5.0 & 5.6 & 5.0 \\
\hline Pretreatment & 10.2 & 10.0 & 6.4 & 6.4 \\
\hline Hydrolysis and fermentation & 9.0 & - & 10.1 & - \\
\hline Distillation and dehydration & 7.8 & - & 7.7 & - \\
\hline Biogas production & - & 21.9 & - & 21.7 \\
\hline Biogas upgrading/compression & - & 21.8 & - & 21.5 \\
\hline Water treatment & 2.3 & 1.3 & 2.3 & 1.3 \\
\hline Utility & 4.5 & 2.6 & 4.4 & 2.5 \\
\hline Storage & 1.5 & 3.6 & 1.3 & 3.4 \\
\hline Working capital & 3.1 & 3.5 & 2.7 & 3.3 \\
\hline Total project investment & 44.0 & 69.7 & 40.5 & 65.1 \\
\hline
\end{tabular}

TABLE 5: The manufacturing cost of biofuels and the tax portion of the final prices.

\begin{tabular}{|c|c|c|c|c|c|c|c|}
\hline Cost $(€ / \mathrm{L})$ or $\left(€ / \mathrm{m}^{3}\right)$ & Product cost & $30 \%$ tax on plant income & Energy tax & $\begin{array}{c}\text { Carbon } \\
\text { dioxide tax }\end{array}$ & $25 \% \mathrm{VAT}^{1}$ & Final Price & $\begin{array}{l}\text { Final price } \\
\text { (gasoline } \\
\text { equivalent) }\end{array}$ \\
\hline Gasoline $^{2}$ & 0.70 & - & 0.34 & 0.28 & 0.33 & 1.65 & 1.65 \\
\hline $\mathrm{E} 85^{3}$ & 0.82 & - & 0.05 & 0.04 & 0.23 & 1.14 & 1.59 \\
\hline Biomethane $100^{4}$ & 1.26 & - & - & - & 0.31 & 1.57 & 1.39 \\
\hline \multicolumn{8}{|l|}{ Manufacturing cost ${ }^{5}$} \\
\hline Bioethanol $^{6}$ (scenario 1) & 0.63 & 0.07 & - & - & $0.23^{7}$ & 0.93 & 1.40 \\
\hline Biomethane $^{8}$ (scenario 2) & 0.97 & 0.07 & - & - & $0.31^{9}$ & 1.35 & 1.20 \\
\hline Bioethanol $^{6}$ (scenario 3) & 0.50 & 0.10 & - & - & $0.23^{7}$ & 0.83 & 1.24 \\
\hline Biomethane ${ }^{8}$ (scenario 4) & 0.77 & 0.09 & - & - & $0.31^{9}$ & 1.17 & 1.04 \\
\hline \multicolumn{8}{|c|}{$\begin{array}{l}{ }^{1} \text { VAT is calculated as } 25 \% \text { of the product prices of biomethane which were } 10.9 \mathrm{SEK} / \mathrm{m}^{3}\left(1.26 € / \mathrm{Nm}^{3}\right) \text { and ethanol which were } 7.9 \mathrm{SEK} / \mathrm{L}(0.82+0.05+0.04= \\
0.91 € / \mathrm{L}) \text {. Therefore, VAT for biomethane }=1.26 * 0.25=0.31 € / \mathrm{Nm}^{3} \text { and VAT for } 85=0.91 * 0.25=0.23 € / \mathrm{L} \text {. } \\
2{ }^{2} \text { Average of gasoline ( } 95 \% \text { octane) in } 2013[4] \text {. The gasoline includes } 5 \% \text { bioethanol. } \\
{ }^{3} \mathrm{E} 85 \text { is a blend of bioethanol and } 15 \% \text { gasoline. During winter time, the portion for gasoline increases to } 25 \% \text {. The portion of fossil fuel in E85 includes energy } \\
\text { and } \mathrm{CO}_{2} \text { tax. } \\
{ }^{4} \mathrm{Biomethane} 100 \text { contains } 100 \% \text { methane from biological sources and is sold in Sweden along with CNG. } \\
{ }^{5} \mathrm{Manufacturing} \text { cost includes selling and distribution expenses which were } 0.06 € / \mathrm{L} \text { for ethanol and } 0.1 € / \mathrm{Nm}^{3} \text { for biomethane. } \\
{ }^{6} \mathrm{The} \text { plant product is } 99.9 \% \text { bioethanol. } \\
{ }^{7} \text { It is assumed that the product will be sold to the market in the same price of E85. Thus, VAT was assumed to be similar to VAT for E85. } \\
{ }^{8} \text { The plant product is } 97 \% \text { biomethane. } \\
{ }^{9} \text { It is assumed that the product will be sold to the market in the same price of biomethane } 100 \text {. Thus, VAT was assumed to be similar to VAT for biomethane }\end{array}$} \\
\hline
\end{tabular}

TABLE 6: The profitability parameters of the processes.

\begin{tabular}{lcccc}
\hline Scenario & 1 & 2 & 3 & 4 \\
\hline Pretreatment & NMMO & NMMO & Steam explosion & Steam explosion \\
\hline Product & Ethanol/biogas & Biomethane & Ethanol/biogas & Biomethane \\
\hline Payback period (year) & 6.3 & 8.3 & 6.2 & 7.6 \\
Net return rate (NRR) (\%) & 14.6 & -6.3 & 16.7 & -3.0 \\
Profitability index (PI) & 1.14 & 0.93 & 1.16 & 0.96 \\
\hline
\end{tabular}


NMMO process, higher capital as well as more expensive raw materials reduced the overall profitability of the processes with NMMO pretreatment. The technoeconomic study for production of biomethane or ethanol shows that the average gasoline equivalent price of biomethane was $16 \%$ lower than that of ethanol and both were 18-39\% lower than the taxed gasoline. The energy and carbon dioxide taxes on the gasoline significantly help this competition in favor of the biofuels. Application of cheaper cellulose solvents improves the economy of the process while maintaining high yields of biofuels.

\section{Conflict of Interests}

The authors declare that there is no conflict of interests regarding the publication of this paper.

\section{Authors' Contribution}

All experiments and paper preparation were done by Marzieh Shafiei, and the rest of the authors supervised the experiments and revised the paper.

\section{Acknowledgments}

The authors are grateful for the financial support from the Swedish Energy Agency and Institute of Biotechnology and Bioengineering, Isfahan University of Technology.

\section{References}

[1] M. J. Taherzadeh and K. Karimi, "Pretreatment of lignocellulosic wastes to improve ethanol and biogas production: a review," International Journal of Molecular Sciences, vol. 9, no. 9, pp. 1621-1651, 2008.

[2] J. Yliopisto, "Evaluation of potential technologies and operational scales reflecting market needs for low-cost gas upgrading systems," Seventh framework programme theme energy, Biowaste as feedstock for 2nd generation, 2009, http://www.valorgas.soton.ac.uk/deliverables.htm.

[3] M. Linné and O. Jönsson, Summary and Analysis of the Potential for Production of Renewable Methane (Biogas and SNG) in Sweden, 2004, http://www.biogasmax.co.uk/media/summary_and _analysis_april2005__022436100_1644_26042007.pdf.

[4] "Så här byggs bensinpriset upp," http://www.preem.se/templates/page_-_791.aspx.

[5] M. Shafiei, K. Karimi, H. Zilouei, and M. J. Taherzadeh, "Enhanced ethanol and biogas production from pinewood by NMMO pretreatment and detailed biomass analysis," BioMed Research International, vol. 2014, Article ID 469378, 10 pages, 2014.

[6] M. Shafiei, K. Karimi, and M. J. Taherzadeh, "Pretreatment of spruce and oak by $\mathrm{N}$-methylmorpholine-N-oxide (NMMO) for efficient conversion of their cellulose to ethanol," Bioresource Technology, vol. 101, no. 13, pp. 4914-4918, 2010.

[7] N. Poornejad, K. Karimi, and T. Behzad, "Improvement of saccharification and ethanol production from rice straw by NMMO and [BMIM][OAc] pretreatments," Industrial Crops and Products, vol. 41, no. 1, pp. 408-413, 2013.
[8] A. Goshadrou, K. Karimi, and M. Lefsrud, "Characterization of ionic liquid pretreated aspen wood using semi-quantitative methods for ethanol production," Carbohydrate Polymers, vol. 96, no. 2, pp. 440-449, 2013.

[9] N. Poornejad, K. Karimi, and T. Behzad, "Ionic liquid pretreatment of rice straw to enhance saccharification and bioethanol production," Journal of Biomass to Biofuel, vol. 1, pp. 8-15, 2014.

[10] A. Aden and T. Foust, "Technoeconomic analysis of the dilute sulfuric acid and enzymatic hydrolysis process for the conversion of corn stover to ethanol," Cellulose, vol. 16, no. 4, pp. 535545, 2009.

[11] A. Ekman, O. Wallberg, E. Joelsson, and P. Börjesson, "Possibilities for sustainable biorefineries based on agricultural residues-a case study of potential straw-based ethanol production in Sweden," Applied Energy, vol. 102, pp. 299-308, 2013.

[12] M. Shafiei, K. Karimi, and M. J. Taherzadeh, "Technoeconomical study of ethanol and biogas from spruce wood by NMMO-pretreatment and rapid fermentation and digestion," Bioresource Technology, vol. 102, no. 17, pp. 7879-7886, 2011.

[13] M. Shafiei, M. M. Kabir, H. Zilouei et al., "Techno-economical study of biogas production improved by steam explosion pretreatment," Bioresource Technology C, vol. 148, pp. 53-60, 2013.

[14] "Product benefits of Cellic CTec3," http://bioenergy.novozymes .com/en/cellulosic-ethanol/CellicCTec3/product-description /Pages/default.aspx.

CellicCTec3/product-description/Pages/default.aspx.

[15] J. D. Murphy and N. Power, "Technical and economic analysis of biogas production in Ireland utilising three different crop rotations," Applied Energy, vol. 86, no. 1, pp. 25-36, 2009.

[16] L. D. Baere, The Dranco Technology: A Unique Digestion Technology for Solid Organic Waste, 2010, http://www.ows.be/wp-content/uploads/2013/02/The-DRANCO-technology-2012.pdf.

[17] M. Abdal, Private Communications, Sepahan Biological Products Company, Isfahan, Iran, 2014.

[18] M. Sadeghi, Private Communications, Parsian Pooya Polymer Company, Isfahan, Iran, 2014.

[19] A. Sanches-Pereira and M. F. Gómez, "Towards a cleaner vehicle fleet: the dynamics of the Swedish biofuel system," in International Workshop Advances in Cleaner Production, UNIP, Sao Paulo, Brazil, 2013.

[20] "Combined heat and power production in Sweden," http://www.fortum.com/en/energy-production/combinedheat-and-power/sweden/pages/default.aspx.

[21] L. Borden and M. S. Arwidson, "Products from the foresta natural choice," The Swedish Forest Industry's Sustainability, 2008.

[22] S. Kumar, "Hydrothermal processing of biomass for biofuels," Biofuel Research Journal, vol. 1, no. 2, pp. 34-43, 2014.

[23] "Optimize design and operations with Aspen ONE Engineering," http://www.aspentech.com/products/aspenone -engineering/.

[24] R. J. Wooley and V. Putsche, "Development of an Aspen Plus physical property database for biofuels components," Tech. Rep. NREL/MP-425-20685, National Renewable Energy Laboratory, US Department of Energy Laboratory, 1996.

[25] A. Aden, M. I. Ruth, K. Ibsen et al., "Lignocellulosic biomass to ethanol process design and economics utilizing co-current dilute acid prehydrolysis and enzymatic hydrolysis for corn stover," NREL/TP 510-32438, National Renewable Energy Laboratory, US Department of Energy Laboratory, 2002. 
[26] M. Persson, "Evaluation of upgrading techniques for biogas," 2003, http://cdm.unfccc.int/filestorage/E/6/T/E6TUR 2NNQW9O83ET10CX8HTE4WXR2O/Evaluation\%20of\%20 Upgrading\%20Techniques\%20for\%20Biogas.pdf?t=WGd8bXp ud2dpfDApZg3J-NNGYnJKCGkI9FnI.

[27] M. S. Peters and K. D. Timmerhaus, Plant Design and Economics for Chemical Engineers, McGraw Hill, New York, NY, USA, 1991.

[28] Price history, 2014, http://www.jet.se/sv_SE/pg1334073843105/ private/Priser/Prishistorik.html.

[29] Convert Euros to Swedish Krona, 2014, http://www.currency .me.uk/convert/eur/sek. 

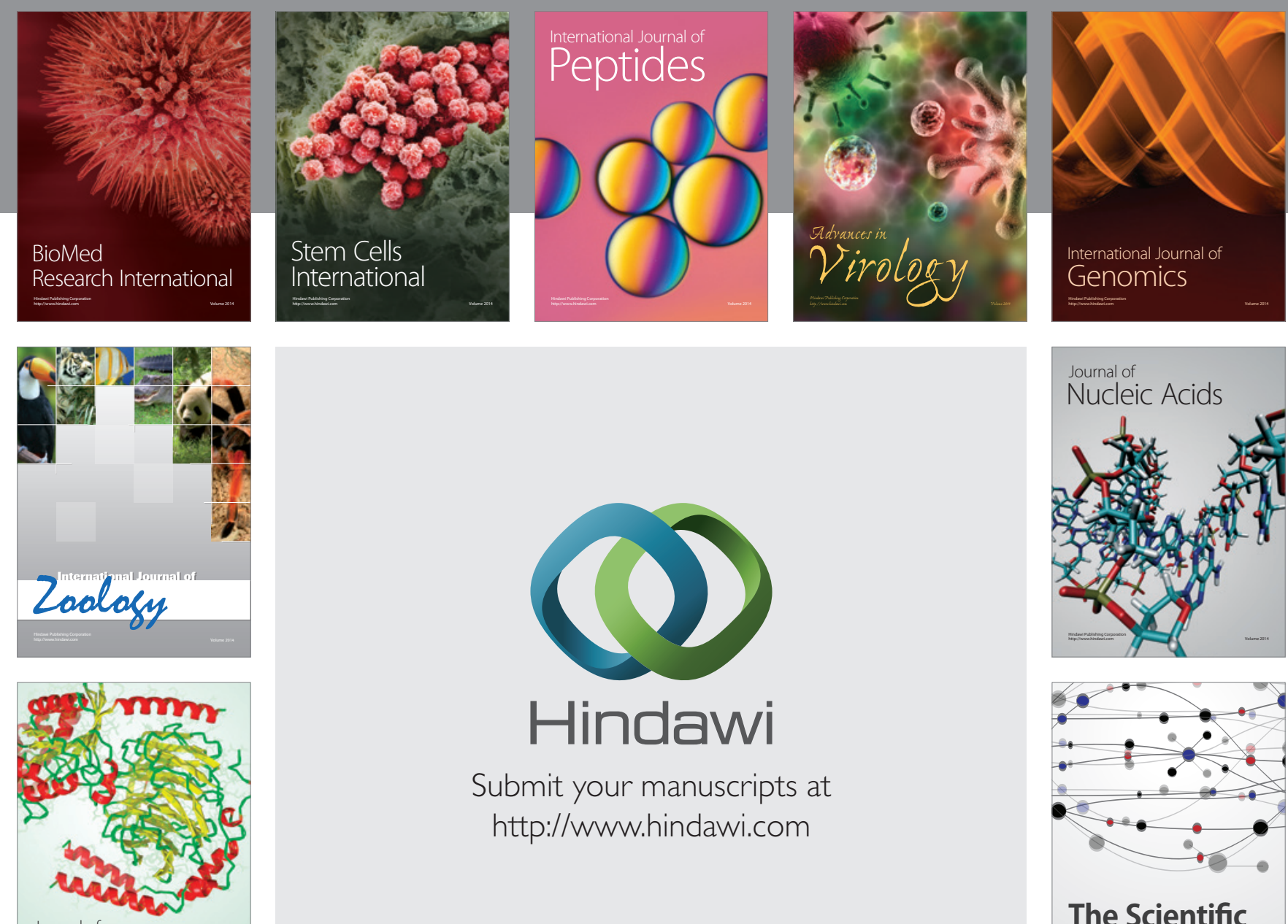

Submit your manuscripts at

http://www.hindawi.com

Journal of
Signal Transduction
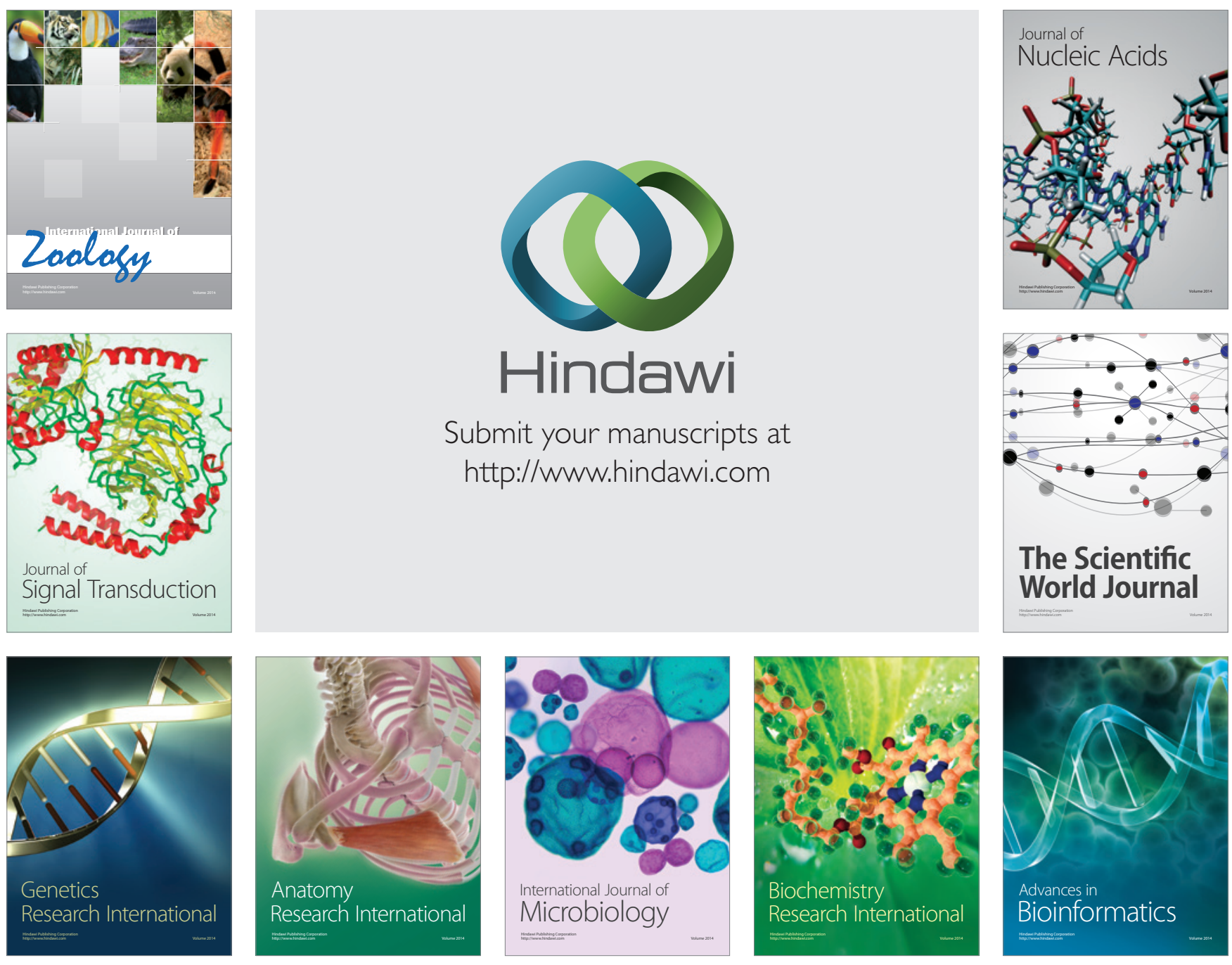

The Scientific World Journal
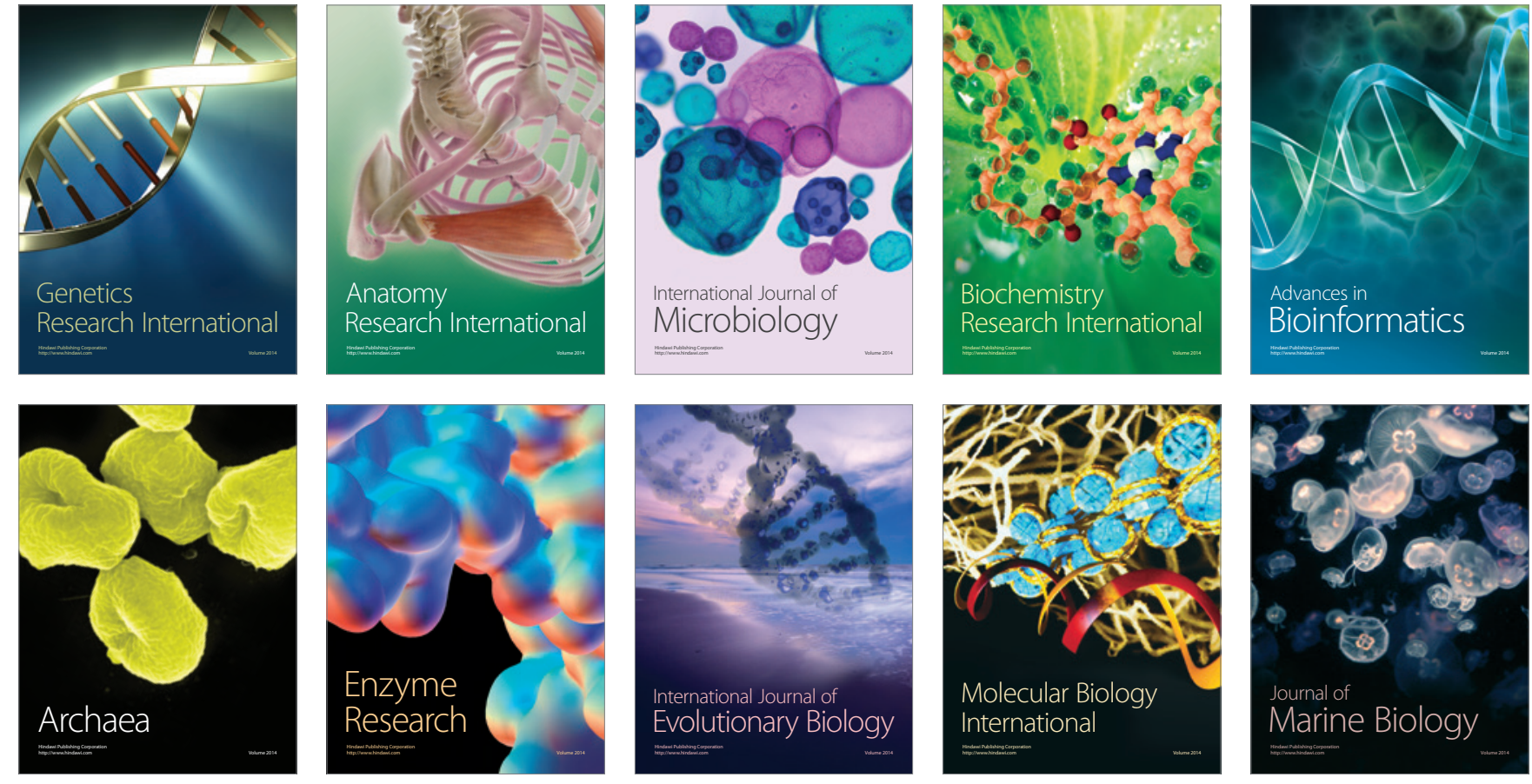